Dept. of Animal Med. (Infectious Disease)s,

Faculty of Vet. Med. Assiut Univ., (amazaitoun@yahoo.com)

\title{
MOLECULAR DETECTION OF MYCOPLASMA INFECTION IN MILK OF CLINICALLY MASTITIC BUFFALOES
}

(With 3 Tables and 5 Figures)

By

\author{
A.M.A. ZAITOUN
}

(Received at 20/4/2009)
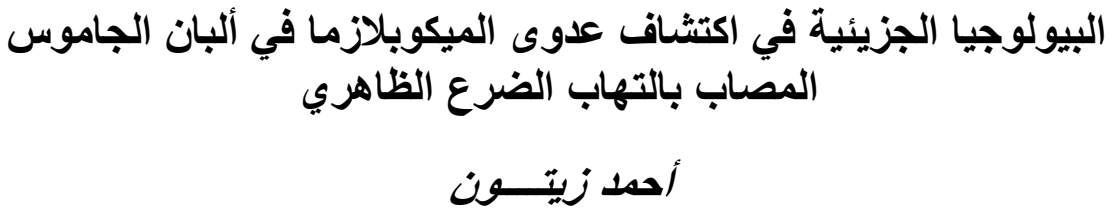

الهدف من إجر اء البحث معرفة مدى إنتشار التهاب الضرع المسبب بالميكوبلازما في في الجاموس الحلوبة. خلال فترة البحث تم الفحص الظاهري لعدد 1250 جاموسة بقرى مختلفة

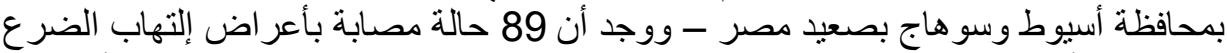

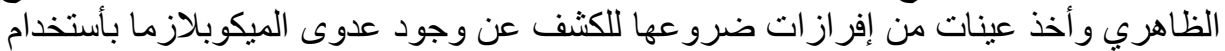
إختبار البلمرة التسلسلي التفاعلي ( PCR ). وقد تم تقسيم الحيو انات المريضة إكلينيكيا - طبقا

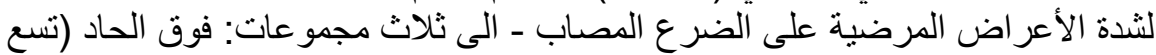

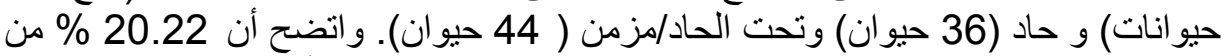

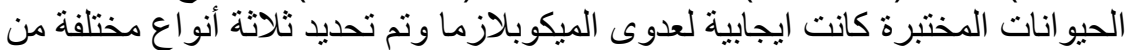
الميكوبلازما: 1-3 Mycoplasma bovirhinus -2 Mycoplasma bovigenitalium Mycoplasma arginini

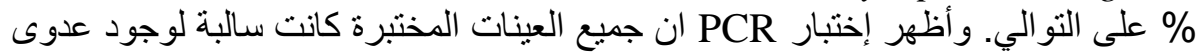
ميكوبلازما الأبقار ( Mycoplasma bovis) وكانت عدوى ميكوبلاز ما الأبقار التناسلية

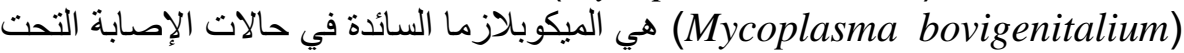

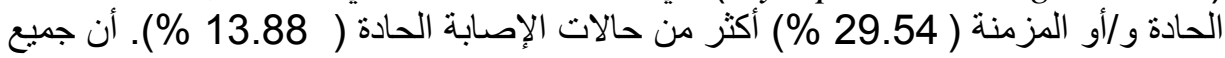

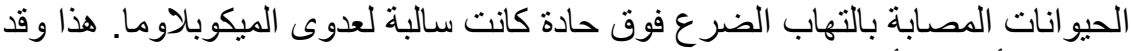

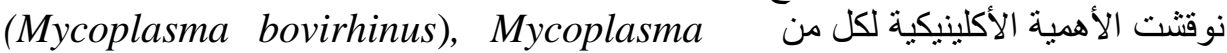

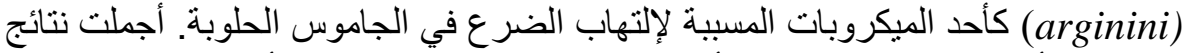

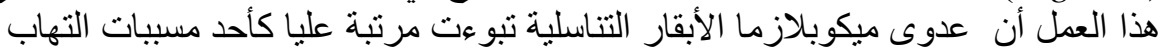

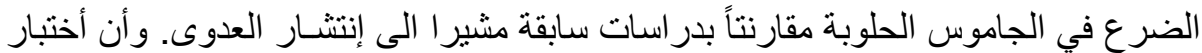

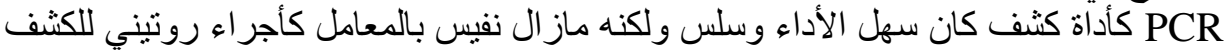
عن مرض التهاب الضرع خاصة في المز الارع الصغيرة أو مار حالات الأهالي. 
Prevalence of Mycoplasma infection in private cases of buffaloes with clinical mastitis was fundamentally goaled. During five years investigation, 1250 primiparous and multiparous dairy buffaloes located in different villages of Assiut and Sohag Governorates, South Egypt were clinically inspected. Eighty-nine cases showed signs of clinical mastitis and their mammary secretions were tested for the presence of Mycoplasma infection using Polymerase Chain Reaction (PCR). The clinically mastitic buffaloes were categorized into peracute (nine cases), acute $(\mathrm{n}=36)$ and subacute/chronic $(\mathrm{n}=44)$ forms. Mycoplasma infection was detected in $20.22 \%$ of the tested buffaloes. All molecularly Mycoplasma positive-buffaloes were multiparous and characterized by recurrent attacks of mastitis. Mycoplasma bovigenitalium, Mycoplasma bovirhinus and Mycoplasma arginini were detected with frequent detection, $58.62 \%, 31.03 \%$ and $10.35 \%$, respectively. All PCR - tested samples were negative to Mycoplasma bovis. Mycoplasma bovigenitalium was a predominant Mycoplasmal mastitis pathogen detected in buffaloes with subacute/chronic $(29.54 \%)$ mastitis rather than acute $(13.88 \%)$ form. Mycoplasma infection could not be detected in buffaloes with peracute mastitis. Clinical significance of the detected Mycoplasma bovirhinus and Mycoplasma arginini as mastitis pathogen was discussed. It can conclude that Mycoplasma bovigenitalium become occupying a considerable grade as a contagious mastitis pathogen in dairy buffaloes in comparison with previous studies referring to spread of infection. PCR as a detecting tool is a manageable contrivance and is easier than conventional culturing procedure, but it is still precious in our laboratories as a routine test for diagnosis of mastitis particularly in smallholder farms and/or private cases.

Key words: Buffaloes, South Egypt, Clinical Mastitis, M. bovigenitalium, M. bovirhinus M. arginini, PCR

\section{INTRODUCTION}

Clinical mastitis incriminated as a critical problem of the dairy animals causing dramatic economic losses during the lactation season. These losses are not only due to losses of quality and quantity of milk production but also due to the spread of infection to the neighboring animals. Moreover, costs of veterinary service, therapeutic trials and control amplify the seriousness of clinical mastitis (Palanivel et al., 2008; Zaitoun, 2008 and Petrovski et al., 2009). Microorganisms causing mastitis are numerous, but mastitis pathogens can be categorized 
as environmental (Escherichia coli) or contagious (Staphylococcus aureus and Mycoplasma species) depending on their primary reservoir (environment versus infected mammary gland) (Edmonson and Bramely, 2004). Mastitis caused by contagious pathogens appears to be more prevalence than the environmental mastitis (Riekerink et al., 2006; Ali et al., 2008 and Zaitoun, 2008 and Petrovski et al., 2009).

Contagious mastitis caused by Mycoplasma infection in cows and buffaloes is a worldwide disease (Nicholas, 2002; Roy et al., 2008 and Nicholas et al., 2009). In Egypt, Mycoplasma isolated from milk of cows by El-Ebeedy et al. (1985), Eissa (1986) and Ahmed (1987) and from buffaloes' milk by Zaitoun (1990). The authors corroborated that Mycoplasma mastitis coming Egypt through importation of infected Friesian cows. Twenty years later, several works on Mycoplasma mastitis in dairy cows and buffaloes on farms and in individual (private) cases at different localities of Delta-region and of South Egypt's Governorates were subsequently published (Zaitoun et al., 1991; ElShabiny, and Abo-El-Makarem, 1994; Zaitoun and Eissa, 1994; Zaitoun, 2000; Ibrahim et al., 2007 and Abdelhameed and Sharaf, 2009). Adbelhameed and Sharaf, (2009) carried out a wide survey on Mycoplasma infection on various smallholder farms of large dairy ruminants in mid-area of Delta region of Egypt. They concluded that Mycoplasma infection is develop into a significant risk on Friesian farms and occupied a considerable level as mastitis pathogen in Delta region of Egypt. These may noticeably refers to the spread of Mycoplasma infection throughout the Egyptian farms and it may become inherent or endemic in some areas. Various types of Mycoplasma were isolated from large dairy ruminants with intramammary infections in Egypt. However, Mycoplasma bovis and Mycoplasma bovigenitalium are still the most important causes of Mycoplasma mastitis in Egypt (El-Ebeedy et al. (1985); Zaitoun et al., 1991; El-Shabiny, and Abo-El-Makarem, 1994; Ibrahim et al., 2007 and Abdelhameed and Sharaf, 2009).

Buffaloes consider the first source of animals' resources for milk yield rather than meat production in Egypt. They produce approximately $65 \%$ (or may be more) of milk production (Mostageer, 1989 and Metry, 1996). More than $90 \%$ of the Egyptian buffaloes' population is apparently still under the villagers' hands as private cases rather than that those kept on farms (Mostageer, 1989). However, the most of published literature on mastitis in Upper Egypt are focused on dairy Friesian and buffaloes farms (El-Gamal, 1989; El-Shabiny, and Abo-El-Makarem, 1994 and Seddek et al., 1999). During the past 15 years, field data on 
prevalence of Mycoplasma mastitis of dairy buffaloes in south Egypt could not be traced on the available literature and appears to be scarce. Consequently, the aim of the present work was to elucidate the prevalence of Mycoplasma mastitis of dairy buffaloes with clinical mastitis in different villages of Assiut and Sohag Governorates, South Egypt, using PCR technique.

\section{MATERIALS and METHODS}

\section{Animal:}

During the period, June 2002 to September 2007, a total number of 1250 dairy buffaloes (private cases) located in different villages of Assiut and Sohag Governorates, Upper Egypt, were clinically inspected and their mammary glands were carefully examined for detection of gross udders and milk abnormalities. Eighty-nine cases of the inspected buffaloes showed signs of clinical mastitis (udder and/or milk abnormalities). Based on the number of parturitions (lactation seasons), the diseased cases were grouped into primiparous $(n=14)$ and multiparous $(n=75)$ and they were manually milked twice daily. The majority of the owners have no awareness concerning pre - and/or post-milking sanitations or dried-period therapy. History of previous mastitis or reduction of milk yield due to known and/or unknown cause, prior treatment was serially enrolled. Clinically, buffaloes with mastitis were categorized into three forms: peracute $(n=9)$, acute $(n=36)$, subacute/chronic $(\mathrm{n}=44)$ with and/or without systemic reaction based on the outlines illustrated by Jackson and Cockcroft (2002).

\section{Samples collection and technical procedure:}

A composite sample (approx. $25 \mathrm{ml}$ of mammary secretion) from the infected quarter(s) of each diseased buffalo was collected in a sterile screw capped bottle. The collected samples were reserved frozen until examination. The time interval between the samples collection and the Mycoplasma examination was a month. The frozen sample was thawed and thoroughly vortexed and half milliliter of the content was pipetted, immersed into $1.5 \mathrm{ml}$ of modified Hayflick's broth medium containing inhibitors to suppress bacterial population and to enhance the growth of Mycoplasma cells and incubated at $37{ }^{\circ} \mathrm{C}$ (Zaitoun, 1990). Two days later, a milliliter of the incubated broth was transferred to $10 \mathrm{ml}$ of modified Hayflick's broth medium and incubated at $37{ }^{\circ} \mathrm{C}$ for three consecutive days. These broths were tested for the presence of Mycoplasmas. 


\section{PCR procedure for identification of Mycoplasma:}

Specific-species primers of Mycoplasma bovis, Mycoplasma bovigenitalium, Mycoplasma bovirhinus and Mycoplasma arginini were used for molecular examination of the collected samples.

The PCR procedure for detection of Mycoplasma bovis was carried out according to the protocol illustrated by Lunini et al. (2006) and Radaelli et al. (2008). Briefly, the incubated broth sample was harvested for $30 \mathrm{~min}$ at $14000 \mathrm{xg}$. The pellet was washed and resuspended in $300 \mu \mathrm{l}$ of distilled water treated with $0.1 \%$ of diethylpyrocarbonate and the DNA was extracted from $100 \mu 1$ using the DNeasy Tissue Kit (QIAamp ${ }^{\circledR}$ DNA Mini, Qiagen ${ }^{\circledR}$ ) based on outlines of the manufacturer.

Specific primers of Mycoplasma bovis were designed for PCR (MYCBV-Fw - 5'-TAT CGG TGA CCC TTT TGC AC-3' ; MYCBV$\mathrm{Rw}$ - 5'-TTC CAC TTC CTG ACT CAC CA-3') that would amplify a fragment of $348 \mathrm{bp}$ of the oppD (oligopeptide permease $\mathrm{D}$ ) gene of Mycoplasma bovis. A final volume of $20 \mu \mathrm{l}$ was used containing $0.2 \mu \mathrm{M}$ of each primer, $200 \mu \mathrm{M}$ of dNTPs, 2 units of Taq polymerase (Roche Diagnostics), $1 \times 1.5 \mathrm{mM}$ of $\mathrm{MgCl}_{2}$ and $5 \mu \mathrm{l}$ of the extracted DNA. The following amplification procedure was used: $95{ }^{\circ} \mathrm{C}$ for $5^{\prime}, 36$ cycles at $95{ }^{\circ} \mathrm{C}$ for $1^{\prime}, 59{ }^{\circ} \mathrm{C}$ for $30^{\prime \prime}$ and $72{ }^{\circ} \mathrm{C}$ for $30^{\prime \prime}$ and 72 for $7^{\prime}$. Ten microliters of the amplified product were analyzed by electrophoresis in a $1.8 \%$ (wt / vol) agarose gel (Agarose, MP, Multi purpose agarose, Boehringer Manheim) and thereafter stained with ethidium bromide $(0.5 \mu \mathrm{g} / \mathrm{ml})$ stain and photographed.

On the other hand, specific primers of Mycoplasma bovigenitalium (Kobayashi et al., 1998), Mycoplasma bovirhinus (Kobayashi et al., 1998) and Mycoplasma arginini (Timenetsky et al., 2006) were also incorporated in molecular detection of the examined samples according to the protocol illustrated by the publishers. The sequences of the selected primers are tabulated in Table 1. Unfortunately, reference strains of Mycoplasmas could not be obtained. Consequently PCR products were sequenced with an automatic capillary system (Applied-Biosystem ${ }^{\circledR}$ ) to confirm the specificity of the reaction. The PCR procedure was carried out in Dept. of Animal Med., Faculty of Vet. Med., Assiut University.

\section{RESULTS}




\section{PCR Technique and Prevalence of Mycoplasma infection:}

PCR technique revealed that 18 of 89 tested samples were positive to Mycoplasma infection and three different species of Mycoplasma were detected. All peracute cases of mastitis were molecularly negative to Mycoplasma infection, in contrast to the remained cases (acute and chronic mastitis) (Table 2). On the other hand, all Mycoplasma positive- buffaloes were multiparous and characterized by recurrent attacks of mastitis.

The prevalence (\% affected) of Mycoplasma infection of the examined diseased buffaloes with different forms of clinical mastitis is illustrated on Table 2, which revealed that $20.22 \%$ of the PCR-tested samples were infected by Mycoplasma. Thirteen buffaloes $(72.22 \%)$ of the Mycoplasma-infected-cases $(\mathrm{n}=18)$ were associated with subacute/chronic mastitis, and the remainders $(27.78 \%)$ were associated with acute mastitis (Fig. 1).

Detection of different species of Mycoplasma infection of the examined diseased buffaloes with Mycoplasma mastitis $(n=18)$ was tabulated on Table 3. The frequent distribution of the molecularly detected Mycoplasma species was figured in Fig. 2

Mycoplasma bovigenitalium was the predominant detected Mycoplasmas (Fig. 3). Both Mycoplasma bovirhinus (Fig. 4) and Mycoplasma arginini (Fig. 5) were also molecularly detected in the investigated samples. On the other hand, all PCR - tested samples were negative to Mycoplasma bovis.

Table 1: Nucleotide sequences of the PCR primers used for detection of Mycoplasma bovigenitalium (Mbg) Mycoplasma bovirhinus (Mbr) and Mycoplasma arginini (Marg).

\begin{tabular}{|l|l|c|}
\hline \multicolumn{1}{|c|}{ Species } & \multicolumn{1}{|c|}{ Sequence } & $\begin{array}{c}\text { Size of PCR } \\
\text { product (bp) }\end{array}$ \\
\hline Mbg & $\begin{array}{l}\text { 5'-CGT AGA TGC CGC ATG GCA TTT ACG G-3' } \\
\text { 5'-CAT TCA ATA TAG TGG CAT TTC CTA C-3' }\end{array}$ & $\mathbf{3 1 2}$ \\
\hline Mbr & $\begin{array}{l}\text { 5'-GCT GAT AGA GAG GTC TAT CG-3 } \\
\text { 5'-ATT ACT CGG GCA GTC TCC-3 }\end{array}$ & $\mathbf{3 1 6}$ \\
\hline Marg & $\begin{array}{l}\text { 5' GCATGGAATCGCATGATTCCT 3' } \\
\text { 5' GGTGTTCTTCCTTATATCTACGC 3' }\end{array}$ \\
\hline
\end{tabular}

Table 2: Prevalence of Mycoplasma infection of the examined dairy buffaloes with different forms of clinical mastitis. 


\begin{tabular}{|c|c|c|c|c|c|}
\hline \multirow{2}{*}{$\begin{array}{l}\text { Number of } \\
\text { diseased } \\
\text { buffaloes }\end{array}$} & \multirow{2}{*}{$\begin{array}{l}\text { Clinical } \\
\text { condition of the } \\
\text { infected udder }\end{array}$} & \multirow{2}{*}{$\begin{array}{l}\text { Number of } \\
\text { the diseased } \\
\text { cases }\end{array}$} & \multicolumn{3}{|c|}{ Mycoplasma infection } \\
\hline & & & $\begin{array}{l}\text { Positive } \\
\text { cases }\end{array}$ & $\begin{array}{l}\% \text { of } \\
\text { infection }\end{array}$ & Total \\
\hline \multirow{3}{*}{89} & Peracute & $9(10.11 \%)$ & 0 & 0 & \multirow{3}{*}{$\begin{array}{c}18 \\
(20.22 \%)\end{array}$} \\
\hline & Acute & $36(40.45 \%)$ & 5 & 13.88 & \\
\hline & Subacute/chronic & $44(49.44 \%)$ & 13 & 29.54 & \\
\hline
\end{tabular}

The numbers between parentheses are the percentages of infection to all mastitis cases $(n=89)$

Table 3: Detection of Mycoplasma species in the diseased buffaloes with Mycoplasma mastitis $(\mathrm{n}=18)$.

\begin{tabular}{|l|c|l|}
\hline $\begin{array}{l}\text { Clinical condition of } \\
\text { the diseased udder }\end{array}$ & $\begin{array}{c}\text { Number of } \\
\text { diseased buffaloes }\end{array}$ & $\begin{array}{c}\text { Type of Mycoplasma, } \\
\text { detected by PCR } \\
\text { technique }\end{array}$ \\
\hline Acute mastitis & 3 & Mycoplasma bovigenitalium \\
\hline Acute mastitis & 2 & $\begin{array}{l}\text { Mycoplasma bovigenitalium } \\
\text { Mycoplasma bovirhinus }\end{array}$ \\
\hline Subaute/chronic mastitis & 1 & Mycoplasma arginini \\
\hline Subaute/chronic mastitis & 4 & Mycoplasma bovigenitalium \\
\hline Subaute/chronic mastitis & 5 & $\begin{array}{l}\text { Mycoplasma bovigenitalium } \\
\text { Mycoplasma bovirhinus }\end{array}$ \\
\hline Subaute/chronic mastitis & 2 & $\begin{array}{l}\text { Mycoplasma bovigenitalium } \\
\text { Mycoplasma bovirhinus } \\
\text { Mycoplasma arginini }\end{array}$ \\
\hline Subaute/chronic mastitis & 1 & Mycoplasma bovigenitalium \\
\hline
\end{tabular}


Fig. 1: Mycoplasma infection (\% affected) in the various forms of clinical mastitis of buffaloes

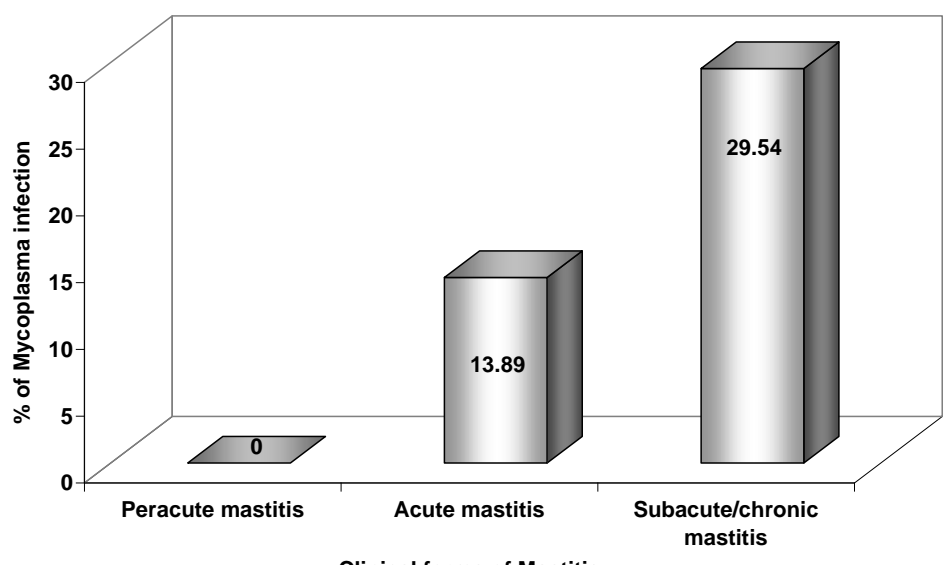

Clinical forms of Mastitis

Fig. 2: Frequent distribution of the molecularly detected mycoplasma species of the examined diseased buffaloes with mycoplasma mastitis $(n=18)$

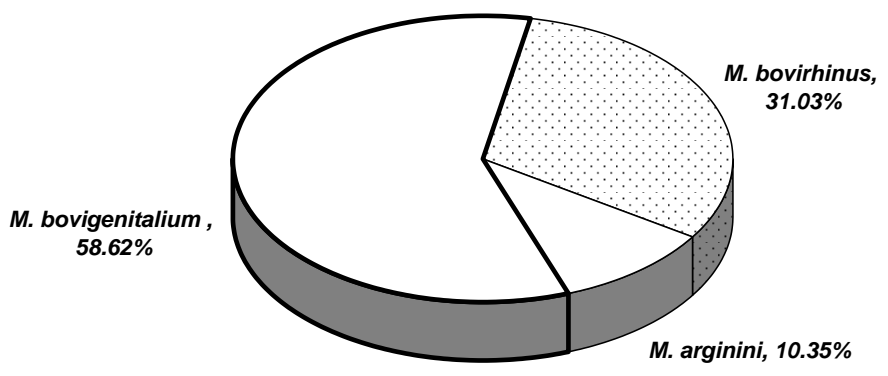


Fig. 3: Ethidium bromide-stained, $1.8 \%$ agarose gel showing the reaction product of PCR amplification. The white arrow refers to the size of PCR product of Mycoplasma bovigenitalium, $312 \mathrm{bp}$

Lane 1: Molecular weight marker, (Sigma, 100 bp ladder) Lane 2 -5: Positive samples to Mycoplasma bovigenitalium Lane 6: Negative sample

Lane 7 - 12: Positive samples to Mycoplasma bovigenitalium

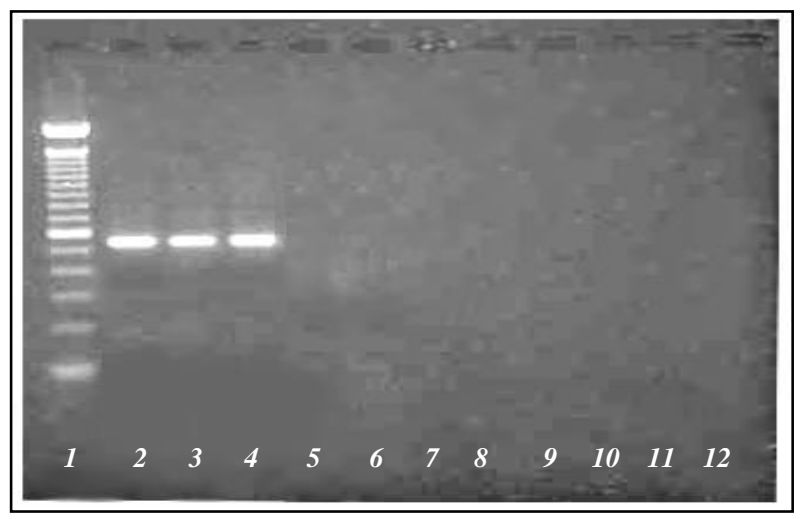

Fig. 4: Ethidium bromide-stained, $1.8 \%$ agarose gel showing the reaction product of PCR amplification. The white arrow refers to the size of PCR product of Mycoplasma arginini, $545 \mathrm{bp}$

Lane 1: Molecular weight marker, (Sigma, 100 bp ladder)

Lane 2 - 4: Positive samples to Mycoplasma arginini Lane 5 - 12: Negative samples 


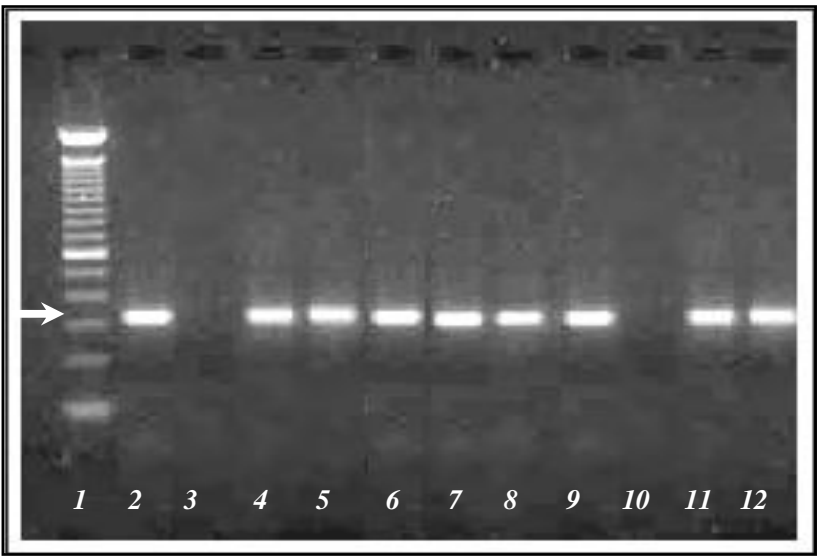

Fig. 5: Ethidium bromide-stained, $1.8 \%$ agarose gel showing the reaction product of PCR amplification. The white arrow refers to the size of PCR product of Mycoplasma bovirhinus, $316 \mathrm{bp}$

Lane 1: Molecular weight marker, (Sigma, $100 \mathrm{bp}$ ladder)

Lane 2: Positive samples to Mycoplasma bovirhinus

Lanes 3 \& 10: Negative samples

Lane 4 - 9: Positive samples to Mycoplasma bovirhinus

Lanes 11 \&12: Positive samples to Mycoplasma bovirhinus

\section{DISCUSSION}

The current work revealed that $20.22 \%$ of the examined diseased buffaloes with clinical mastitis were molecularly positive to Mycoplasma infection concluding that Mycoplasma occupied a considerable magnitude as an etiologic agent of contagious mastitis pathogen of private dairy buffaloes. Previously Eissa (1986), Zaitoun (1990) and Zaitoun et al. (1991) concluded that the prevalence of Mycoplasma mastitis of dairy buffaloes ranged from 0 to $2.04 \%$ referring to the limitation of Mycoplasma infection at that time. Four years later, Zaitoun and Eissa (1994) carried out a wide-scale survey on Mycoplasma mastitis of dairy buffaloes at different localities of Assiut Governorate using conventional culturing procedure. They found that $17.65 \%$ of the examined animals with clinical mastitis were culturally infected by Mycoplasma. In the present study the higher rate of Mycoplasma infection (20.22\%) than that previously reported by Zaitoun and Eissa (1994) may primarily ascribe to the high sensitivity rate of the applied molecular assay in comparison with conventional culturing procedure. On the other side, highest incidence of clinical 
mastitis caused by Mycoplasma infection in dairy buffaloes was reported by El-Shabiniy and Abo-El-Makarrem (1994). They indicated that the infection rate with Mycoplasma was $25 \%$ of the examined buffaloes with clinical mastitis at Beni-Suef Governorate, south Egypt.

The high level of mastitis caused by contagious mastitis pathogens including Mycoplasma infection in the dairy animals attributes to several causes illustrated by Edmonson and Bramely, (2004) and Palanivel et al. (2008). However, unhygienic sanitary measures during milking and lake and/or defects of pre- and post-milking precautions may play an astonishing role. Moreover, omission or slackness in culling of the dairy buffaloes infected by Mycoplasma mastitis in particular Mycoplasma bovis or Mycoplasma bovigenitalium; consider the utmost point in increasing the prevalence of Mycoplasma mastitis in Egyptian field (Zaitoun, 1990 and Zaitoun,1991).

The results of the current work reveal that Mycoplasma bovigenitalium (58.62 \%), Mycoplasma bovirhinus (31.03\%) and Mycoplasma arginini $(10.35 \%)$ are molecularly detected. The former Mycoplasma is the predominant Mycoplasmal pathogen involved in clinical mastitis of dairy buffaloes in Egypt and is agreement with data from previous studies carried out in north and south Egypt (Ahmed, 1987; Zaitoun, 1990; Zaitoun et al., 1991; Zaitoun and Eissa, 1994 and El-Shabiny and Abo-El-Makarrem, 1994). Mycoplasma bovigenitalium is a worldwide infection and is frequently incriminated as a major pathogenic agent capable of inducing a rang of clinical diseases including mastitis and serious reproductive disorders in cattle and buffaloes in numerous countries including Egypt (Nicholas, 2002). In addition to the incrimination of Mycoplasma bovigenitalium as mastitis pathogens of dairies, this microorganism could induce a severe inflammatory reaction in undeveloped mammary gland of an immature calf (Roy et al., 2008).

On the other side, the present study indicates that Mycoplasma bovirhinus is occupied the second grade following Mycoplasma bovigenitalium of the detected Mycoplasmas from the examined diseased buffaloes with clinical mastitis and this may imply the importance of that germ as a mastitis pathogen in buffaloes. Previous result published by El-Shabiny and Abo-El-Makarrem (1994) referred to Mycoplasma bovirhinus as an unconventional mastitis pathogen responsible for severe clinical mastitis in dairy buffaloes at Beni-Seuf Governorate (south Egypt). However, Gourlay and Howared (1979) and Hirose et al. (2001) concluded that Mycoplasma bovirhinus was a 
secondary respiratory infection rather than mastitis pathogen. Moreover, Ayling et al. (2004) indicated that Mycoplasma bovirhinus was commonly found in ruminants but was thought to be more opportunistic than pathogenic. On the other hand, the current work reveals that Mycoplasma arginini was less frequently detected of milk speciemens of the clinically diseased buffaloes with mastitis and this coincided with previous reports of Eissan (1986), Zaitoun (1990), Zaitoun et al. (1991) and Eissa, and Zaitoun (1994). In fact, role of Mycoplasma arginini in diseases of Egyptian dairy buffaloes is still unclear and need investigations. In cattle, Hirose et al. (2003) and Gagea et al. (2006) indicated that Mycoplasma arginini was isolated from the nostrils and pneumonic lungs of calves and from the lower respiratory tract of cattle with signs of respiratory disease.

Clinically, it is appreciate to indicate that all molecularly positive cases to Mycoplasma infection showed signs of subacute and/or chronic mastitis $(49.45 \%)$ rather than acute $(40.45 \%)$ form, and all tested animals with peracute mastitis were molecularly Mycoplasma free. This may refers that the positive cases are chronically infected with Mycoplasma and the infection may become inherent. Moreover, based on history, buffaloes with subacute/chronic mastitis did not respond well to the antimastitic therapy. Therefore, Mycoplasma testing in paralleling with conventional bacteriological examinations should carry out to buffaloes with incurable mastitis. Moreover, causes of incurable mastitis of private dairy buffaloes should be focused.

The current work concludes that Mycoplasma, in particularly Mycoplasma bovigenitalium, occupied a considerable level as an important etiologic agent responsible for contagious mastitis in buffaloes located in villages of south Egypt. PCR is a rapid detecting assay for diagnosis of Mycoplasma mastitis in contrast to the conventional culturing procedure, which tedious and time consuming. PCR procedure can carried out directly on milk samples for detection of Mycoplasma (Hirose et al., 2001) and this may makes it as a practical for clinical testing. However, from practical point of view, PCR is still an expensive detecting procedure in our laboratories as a routine test for diagnosis of mastitis particularly in smallholder farms and/or private cases.

\section{REFERENCES}


Abdelhameed, F. and Sharaf, I. (2009): Bacteriological studies on mastitis of dairy animals with special reference to mycoplasma infection in Menofia and Kaluobia Governorates, Egypt. Assiut Vet. Med. J., 55, 121, 286 - 305.

Ahmed, A.A. (1987): An outbreak of Mycoplasma bovigenitalium mastitis in Egypt. Egypt. J. Vet. Sci., 24, 1, 45 - 53.

Ali, L.; Muhammed, G.; Arshad, M.; Saqib, M. and Hassan, I.J. (2008): Bacteriology of mastitis buffaloes in Tehsil Samundri of district Faisalabad, Pakistan. Pakistan Vet. J., 28, 1, 31-33.

Ayling, R.D.; Bashiruddin, S.E. and Nicholas R.A. (2004): Mycoplasma species and related organisms isolated from ruminants in Britain between 1990 and 2000. Vet Rec. 2004 Oct 2, 155, 14, 413 416.

Edmonson and, P.W. and Bramely, A.J. (2004): Mastitis: In Bovine Medicine Diseases and Husbandry of Cattle. The $2^{\text {nd }}$ Ed. Edited by Andrews, A. H. (Chief Editor); Blowey, R. W.; Boyed, H. and Eddy, R.G. (contributors) Blackwell Science. Pages 226 - 336.

Eissa, S.I. (1986): Some studies on mycoplasma mastitis of cattle and buffaloes in Egypt. Ph. D. Thesis Faculty of Vet. Med., Alexandria Univ., Egypt.

El-Gamal, B.G.A. (1989): Studies on bacteria causing mastitis in cattle in Assiut. Ph D. Thesis. Faculty of Vet. Med., Assiut Univ., Egypt

El-Ebeedy, A.A.; Gad, A.S.; Rashwan, Amal; Mostafa, A.; El-Ahl, S.S.; Esmail, S. and Allam, N.M. (1985): Isolation of Mycoplasma bovis from an outbreak of bovine mastitis in Egypt. J. Egypt. Vet. Med. Assoc., 45, 1, 247 - 253.

El-Shabiny, L. and Abo-El-Makarem, M. (1994): Rapid diagnosis of mycoplasma infection in buffaloes using immunobinding assay. Vet. Med. J., Giza, 42, 2, $47-49$.

Gagea, M.I.; Kenneth G.; Bateman, T.D.; Beverly J. McEwen, B.J.; Susy Carman, S; Archambault, M; Shanahan, R.A. and Caswell, J.L. (2006): Diseases and pathogens associated with mortality in Ontario beef feedlots. J. Vet. Diagn. Invest., 18,18 - 28.

Gourlay and Howard (1979): Human and Animal Mycoplasmas. In The Mycoplasmas. Edited by Tully, J.G. and Whitcomb, R.F., $1^{\text {st }}$ Ed., Vol. II. Academic Press Inc., New York.

Hirose, K.; Kawasaki, Y.; Kotani, K.; Tanaka, A.; Abiko, K. and Ocawa, $H$. (2001): Detection of mycoplasma in mastitis milk by PCR analysis and culture method. J, Vet. Med. Sci., 63, 6. 691-693. 
Hirose, K.; Kobayashi, H.; Ito, N.; Kawasaki, Y.; Zako, M.; Kotani, K.; Ogawa, H. and Sato, H. (2003): Isolation of Mycoplasmas from nasal swabs of calves affected with respiratory diseases and antimicrobial susceptibility of their isolates. J Vet Med B Infect Dis Vet Public Health. 50. 7, 347- 351.

Ibrahim, A.K.; Amin, A.S. and Yassin, M.H. (2007): Diagnosis of Mycoplasma bovis infection by PCR and dot blot hybridization techniques. Proceeding - the $9^{\text {th }}$ Scientific Congress of Egyptian Society for Cattle Diseases (Luxor - Egypt), 160 - 168.

Jackson, P.G.G. and Cockcroft, P.D. (2002): Clinical examination of udder. In Clinical Examination of Farm Animals. First Ed. Blackwell Science Ltd. Pp 154 - 166.

Kobayashi, H.; Hirose, K.; Worarach, A.; Paugtes, P.; Ito, N.; Morozumi, T. and Yamamoto, K. (1998): In vitro amplification of the $16 \mathrm{~S}$ rRNA Genes from Mycoplasma bovirhinis, Mycoplasma alkalescens and Mycoplasma bovigenitalium by PCR. J. Vet. Med. Sci., 60, 12, 1299 - 1303.

Lunini, M.; Gualdi, V.; Maietti, I.; Vezzosi, F.; La-Malfa, C.; Radaelli, E.; Soriolo, A.; Albeton, A.; Fin, M. and Rodeghiero, M. (2006): Mycoplasma bovis in fattening cattle with respiratory disease. Large Animals Review 6, $11-15$.

Metry, (1996): Buffalo. The main dairy animal in Egypt. Booklet, Academy of Scientific Research and Technology.

Mostageer, A. (1989): Milk production in Egypt. Options Méditerranéennes - Série- Séminaires - $\mathrm{n}^{\circ}$. 6, 31-34.

Nicholas, R.A.J. (2002): Mycoplasma bovigenitalium. Animal Health Compendium, CABI, Wallingford, UK. www.cabi.org

Nicholas, R.; Ayling, R. and McAuliffe, L. (2009): Vaccines for Mycoplasma diseases in animals and man. J. Comp. Pathol., 140, $58-96$.

Palanivel, K.M.; Prabakar, T.G.; Selvasubramanian, S. and Vijayalingam, T.A. (2008): Epidemiology of bovine mastitis in and around Chennai. Indian Journal of Field Veterinarians. 3, 3, 24 - 27.

Petrovski K.R.; Heuer C.; Parkinson T.J. and Williamson N.B. (2009): The incidence and aetiology of clinical bovine mastitis on 14 farms in Northland, New Zealand. New Zealand Journal, 57, 2, $109-115$

Radaelli, E.; Lunini, M.; Loria, G.R.; Nicholas, R.A.J. and Scanziani, E. (2008): Bacteriological, serological, pathological and immunohistochemical studies of Mycoplasma bovis respiratory 
infection in veal calves and adult cattle at slaughter. Res. Vet. Sci., 25, $282-290$.

Riekerink, G.M.; Barkema, H.W.; Veenstra, S.; Poole, D.E.; Dingwell, R.T. and Keefe, G.P. (2006): Prevalence of contagious mastitis pathogens in bulk tank milk in Prince Edward Island. Can. Vet. J., 47, 567-572.

Roy, J.P.; Francoz, D. and Labrecque, O. (2008): Mastitis in a 7-week old calf caused by Mycoplasma bovigenitalium. Vet. J. 176, 3, 403 404.

Seddek, S.R.; Abd El-Kader, H.A. and Abd El-Hafeez, M.M. (1999): Bacteriological studies of subclinical mastitis in Friesian cattle in Assiut Governorate. Assiut Vet. Med. J., 42, 83, 77-88.

Timenetsky, J.; Santos, L.M.; Buzinhani, M. and Mettifogo, E. (2006): Detection of multiple mycoplasma infection in cell cultures by PCR. Brazilian J. Med. Biol. Res, 39, 907 - 914.

Zaitoun, A.M.A. (1990): Role of some mycoplasma species in bovine mastitis. Ph D Thesis, Infectious Diseases, Faculty of Vet Med., Assiut University, Assiut, Egypt.

Zaitoun, A.M.A. (1991): Investigations on bovine mycoplasma mastitis in Upper Egypt. Proceeding. The first Scientific Congress of Cattle Diseases. Egyptian Society for Cattle Diseases. Assiut-Egypt, December 1 - 3, $108-118$.

Zaitoun, A.M.A. (2000): Some studies on mastitis of dairy buffaloes with a particular emphasis to mycoplasma infection. Assiut Vet. Med. J., 78, 44, $82-111$.

Zaitoun, A.M.A. (2008): Clinical mastitis caused by Staphylococcus aureus in dairy buffaloes. Assiut Vet Med., 54, 119, 289 - 310.

Zaitoun, A.M.A.; El-Allawy, T.A.; Abdallah, I.S.; El-Ebeedy, A.A.; Eissa, S.I. and El-Shabiny, L. (1991): Incidence of mycoplasma infection in mastitic cows and buffaloes in Upper Egypt. Assiut Vet. Med. J. 25, 50, $108-114$.

Zaitoun, A.M.A. and Eissa, S.I. (1994): Clinical studies on mastitic buffaloes naturally infected by Mycoplasma bovigenitalium. Assiut Vet. Med. J., 25, 50, 108 - 114. 